\title{
Absence of vertical transmission of infectious salmon anemia virus (ISAV) from individually infected Atlantic salmon Salmo salar
}

\author{
Krista J. Melville, Steven G. Griffiths*
}

Research and Productivity Council (RPC), 921 College Hill Road, Fredericton, New Brunswick E3B 6Z9, Canada

\begin{abstract}
Atlantic salmon Salmo salar L. eggs were collected from grilse that were individually identified as ISAVpositive based on the detection of pathogen in ovarian fluid by RT-PCR. The eggs were fertilised, disinfected and reared under quarantine conditions. To address the possibility of vertical transmission, fertilised eggs, alevins and parr were screened for the virus by SHK-1 cell culture and RT-PCR. In addition, ISAV-negative parr were injected with homogenates of potentially infected eyed eggs. ISAV was not detected in eyed eggs, alevins or parr. No mortalities occurred among fish injected with the egg homogenates. These observations suggest the absence of a vertical transmission route for ISAV infection.
\end{abstract}

KEY WORDS: ISAV · Vertical transmission · Atlantic salmon

Infectious salmon anaemia (ISA) was first identified in an Atlantic salmon hatchery in Norway in 1984 (Thorud \& Djupvik 1988), and was later determined to be caused by a virus (ISAV) following its culture on salmon head kidney cells (SHK-1; Dannevig et al. 1995). However, since initial identification in a hatchery environment, there have been no recorded cases of ISAV occurring in freshwater in Norway. The initial occurrence of the disease in 1984 has since been suggested to be attributable to the use of raw seawater at the affected hatchery (Jarp \& Karlsen 1997). Due to the lack of sensitive diagnostic methods before 1994-1995, it may be suggested that if vertical transmission of ISA were possible it would have been reported from freshwater hatcheries during the previous decade. Experimentally, ISAV is certainly capable of horizontal transmission in freshwater and results in high mortality (Totland et al. 1996). Among the Norwegian veterinary and scientific community, the general consensus is that vertical transmission is not part of the infection cycle of ISAV in Atlantic salmon (e.g. T. Håstein, National Veterinary Institute, Oslo; A. Nylund and B. Hjeltnes, Uni-

•Addressee for correspondence. E-mail: sgriffit@rpc.unb.ca versity of Bergen, pers. comm.). The only existing report dealing specifically with this issue is that of Thorud \& Djupvik (1988). In the latter study, the authors outline the injection of $45 \mathrm{~g}$ Atlantic salmon with homogenates prepared from eggs collected at a site known to have been infected with ISAV. However, contributing broodstock were not individually screened for infection. No mortalities or evidence of subclinical infection were reported.

Since the identification of the virus in Canada for the first time in 1997 (Lovely et al. 1999), and in Scotland the following year (Rodger et al. 1998), there are remaining concerns that the possibility of vertical transmission has not been sufficiently addressed. In the current report, milt and eggs were collected from Atlantic salmon determined to be individually infected with ISAV. Eggs were fertilised and disinfected in a quarantine environment and allowed to develop into fry in order to permit further sampling and screening.

Materials and methods. Analysis of broodstock: Grilse from 2 independent sites in the Bay of Fundy were spawned in December 1997. Both sites were previously found to be positive for ISAV as determined by the culture on the salmon head kidney cell line (SHK-1; Dannevig et al. 1995). Bacteriology was performed on all the grilse and reproductive fluids as described in Griffiths et al. (1996); virology of organ tissue and RTPCR (reverse transcriptase-polymerase chain reaction) as described in Lovely et al. (1999) (Method 1). Virology of ovarian fluid was performed by the centrifugation of $1 \mathrm{ml}$, washing the resulting tissue pellet with an equal volume of Hanks' saline, $0.45 \mu \mathrm{m}$ filtration and application of $200 \mu \mathrm{l}$ of the filtrate to SHK-1 cell culture as previously described (Lovely et al. 1999).

Fertilisation: Fertilisation and disinfection of eggs were conducted under quarantine conditions. A single male was crossed with a single female. The eggs were disinfected with Ovadine (Syndel International Inc., Vancouver, $\mathrm{BC}$ ) for $10 \mathrm{~min}$ at $100 \mathrm{ppm}$. In total, 13 pairs 
of fish were spawned. Triplicate samples of eyed eggs (5 eggs sample ${ }^{-1}$ ) from each egg lot were plated onto the SHK-1 cell line.

Analysis of hatched fish: One week following hatching, 10 alevins from each of 3 potentially infected egg lots were pooled and homogenized in Hanks' saline $(10 \%$ w/v) using a Fast Prep 120 (Savant Bio 101 Vista, CA) diluted 5-fold, $0.45 \mu \mathrm{m}$ filtered and $200 \mu \mathrm{l}$ plated onto the SHK-1 cell line (Lovely et al. 1999). Homogenised alevin material was also examined for the presence of viral RNA by RT-PCR. Negative controls for the RT-PCR test included RNA from ISAV negative kidney tissue and the substitution of template with distilled deionised water $\left(\mathrm{dd}_{2} \mathrm{O}\right)$. Positive controls consisted of kidney tissue RNA extracted from clinically infected parr. Repeat testing was conducted on a pool of 10 fry from each of the 3 potentially infected groups 3 wk after first-feeding. Total RNA was purified from alevin and fry homogenates using Trizol LS following manufacturer's instructions (Life Technologies, Gaithersburg, MD)

In February 1999, i.e. 16 mo following fertilisation, 10 parr were individually analysed for the presence of ISAV by RT-PCR following the extraction of RNA from gill and kidney tissue in addition to gill mucus. A modification to the existing RT-PCR method (Method 2) was adopted in that a shorter amplification product was produced from within the previously targeted sequence. The primer pair FA3 (gaagagtcaggatgccaagac) and RA3 (gaagtcgatgatgatctgcagcga) amplified a 221 bp product and were suggested to be highly sensitive for diagnostic work (A. Nylund pers. comm.). Eight pmol of each primer were incorporated into the ReadyTo-Go RT-PCR system (Amersham-Pharmacia Biotech, Uppsala, Sweden). The change in RT-PCR format was adopted due to the increase in sensitivity associated with the FA3/RA3 combination in comparison to the previous method (data not shown). In addition, the decision was influenced by a report describing the continuous 2-enzyme RT-PCR (typical of the ReadyTo-Go system) to be the most sensitive of 3 possible RT-PCR formats (Sellner \& Turbett 1998). Magnesium concentration of the kit buffer was increased $0.5 \mathrm{mM}$ to bring the final concentration to $2.5 \mathrm{mM}$. The reverse transcriptase step was performed with random hexamers using incubation times recommended by the manufacturer. Primers were added in a $10 \mu \mathrm{l}$ volume to the $40 \mu \mathrm{l}$ of cDNA mixture followed by 35 cycles of $94^{\circ} \mathrm{C}$ for $30 \mathrm{~s}, 61^{\circ} \mathrm{C}$ for $45 \mathrm{~s}$ and $72^{\circ} \mathrm{C}$ for $90 \mathrm{~s}$. Analysis of amplification product was as previously described (Lovely et al. 1999). Negative controls included RNA from ISAV-negative kidney tissue and the substitution of template with distilled deionised water. Positive controls consisted of kidney tissue and mucus RNA extracted from clinically infected parr.
Challenge of fish with egg homogenates from ISAVinfected fish: Ninety Atlantic salmon parr, average weight $35 \mathrm{~g}$, previously testing negative for ISAV by SHK-1 cell culture, were injected intraperitoneally with $200 \mu \mathrm{l}$ of $0.45 \mu \mathrm{m}$ filtered, $10 \%$ eyed-egg homogenates from each of the 3 ISAV positive broodstock. A control tank included unchallenged fish and fish injected with egg homogenates from ISAV-negative fish. All fish were marked for identification and kept in $1 \mathrm{~m}$ diameter tanks with a freshwater flow of $51 \mathrm{~min}^{-1}$ at a temperature of $11^{\circ} \mathrm{C}$. All surviving fish were euthanised at $80 \mathrm{~d}$ post challenge. Five fish from each group were processed for culture on the SHK-1 cell line (Lovely et al. 1999). Samples of kidney tissue were fixed in $10 \%$ neutral buffered formalin and sent to D. Groman (Atlantic Veterinary College, Charlottetown, Prince Edward Island, Canada) for histopathological screening of ISA and/or haemorrhagic kidney syndrome (HKS; Byrne et al. 1998) as described in Mullins et al. (1998).

Results. Analysis of broodstock, eggs and hatched fish: Of 13 pairs of grilse spawned, 8 of the resulting egg lots were overripe and did not fertilize. Of the 10 grilse contributing to the remaining egg lots, 3 of the 5 females were associated with ISAV-positive ovarian fluid as determined by the occurrence of cytopathology on the SHK-1 cell line with confirmation by RTPCR. ISAV was also detected in the organ pools (gill,

Table 1. ISAV in Salmo salar. ISAV infection status of grilse yielding eggs for the current study. Infection was determined by cell culture on SHK-1 followed by RT-PCR confirmation (Method 1). N/A: reproductive fluid and fish were not analyzed $_{i}$ eggs were overripe and discarded prior to fertilization

\begin{tabular}{|c|c|c|c|c|}
\hline \multirow[b]{2}{*}{$\begin{array}{c}\text { Specimen } \\
\text { no. }\end{array}$} & \multicolumn{2}{|l|}{ Females } & \multicolumn{2}{|c|}{ Males } \\
\hline & $\begin{array}{l}\text { Ovarian } \\
\text { fluid }\end{array}$ & Organs & $\begin{array}{l}\text { Specimen } \\
\text { no. }\end{array}$ & Organs \\
\hline \multicolumn{5}{|l|}{ Site $A$} \\
\hline $1^{a}$ & + & $-b$ & $1^{d}$ & $-b$ \\
\hline $2^{a}$ & - & - & $2^{a}$ & - \\
\hline 3 & - & - & 3 & $-b$ \\
\hline 4 & - & - & 4 & $-^{\mathrm{b}}$ \\
\hline 5 & + & $-b$ & 5 & - \\
\hline $6^{\alpha}$ & + & + & $6^{a}$ & $-{ }^{b}$ \\
\hline $7^{a}$ & - & - & $7^{a}$ & - \\
\hline 8 & N/A & $\mathrm{N} / \mathrm{A}$ & 8 & $N / A$ \\
\hline 9 & N/A & N/A & 9 & $N / A$ \\
\hline 10 & $N / A$ & N/A & 10 & $N / A$ \\
\hline \multicolumn{5}{|l|}{ Site B } \\
\hline 1 & - & - & 1 & - \\
\hline $2^{a}$ & + & + & $2^{\mathrm{a}}$ & - \\
\hline 3 & - & - & 3 & - \\
\hline \multicolumn{5}{|c|}{$\begin{array}{l}\text { 'Progeny from this pairing held in RPC's quarantine unit } \\
\text { 'Organs (gill, spleen, pyloric caecae, and kidney) from } 5 \\
\text { individual fish pooled }\end{array}$} \\
\hline
\end{tabular}


spleen, pyloric caecae and kidney) of 2 of the 3 female broodstock (Table 1). ISAV was not detected in the organ pools from any of the contributing males. No other bacterial or viral pathogens were detected

Between egg fertilisation and fry stages, samples were collected for SHK-1 cell culture and RT-PCR screening. No cytopathic effect (CPE) was observed on the SHK-1 cell line following the plating of eyed-egg or alevin homogenates. No ISAV was detected in the alvevin homogenates using RTPCR Method 1. Repeat testing was performed on 10 alevin from each group 3 wk after first feeding. The virus was not detected by cell culture assay or RT-PCR. As the study progressed, the larvae went through a 2 wk period when they did not seem to feed well or grow. There were approximately 10 mortalities group $^{-1} \mathrm{~d}^{-1}$ during this period. Another type of feed was substituted and mortalities ceased. The mortalities were frozen at $-70^{\circ} \mathrm{C}$. Five individuals from each group were analysed by RT-PCR of kidney homogenates. No ISAV was detected.

Sixteen months after fertilisation, kidney, gill and mucus samples from 10 parr were analysed using the FA3/RA3 primers (Fig. 1). ISAV was not detected. At 23 mo after fertilisation, prior to the introduction of parr to a marine quarantine unit, gill and kidney tissue samples from 10 fish were analysed by RT-PCR using the FA3/RA3 primers. ISAV was not detected. As of

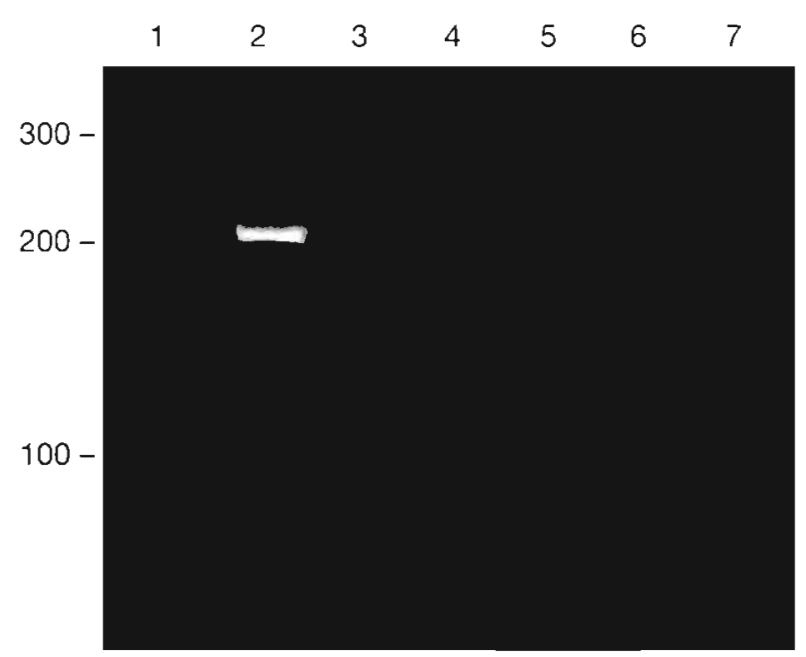

Fig. 1. RT-PCR amplification of ISAV genomic material using primers FA3, RA3. Lane 1: molecular weight standards; Lane 2: ISAV-positive kidney tissue; Lane 3: ISAV-negative kidney tissue; Lane 4: reagent blank ( $\mathrm{dd}_{2} \mathrm{O}$ as template); Lanes 5-7. larval mortalities report preparation, 130 (average $150 \mathrm{~g}$ ) parr originating from infected female fish continue to thrive.

Challenge of fish with egg homogenates from ISAVinfected fish: Results are summarised in Table 2. No ISAV-related mortalities were observed. Five individual fish from each group euthanised at Day 80 post challenge were analysed by cell culture and histopathology. No ISAV was detected.

Discussion. At no time during the sampling of egg homogenates or hatched fish originating from infected female grilse was ISAV detected by the available screening methods. These observations corroborate the findings of Thorud \& Djupvik (1988) and a general consensus among Norwegian researchers that ISAV is not transmitted intra ovum. Historically, there is no evidence for the vertical transmission of ISAV in Norway despite a 14 yr history with the disease in which diagnostic tests have only recently become available. If the current observations reflect the lack of vertical transmission, it may be explained by the absence of appropriate cellular receptors for the virus to enter cells, replicate and maintain an infectious dose during embryogenesis (A. Nylund pers. comm.). However, it is possible that viral titre is below the detection limits of methods used in this study. Unfortunately, the virus does not lend itself to quantitation at low titres in that it does not form plaques. Furthermore, low level infections of the SHK-1 cell line do not always produce cytopathic effects (Falk et al. 1998). As such it is currently not possible to establish a detection limit for RTPCR. We are currently developing an RT-PCR method as a more sensitive index of viral titre, but this will only be semi-quantitative due to the segmented nature of the virus. False negative data may also have arisen from the selection of aliquots from a homogenate with a heterogeneous distribution of virus. However, the lack of morbidity or viral activity in cell culture pro- 
vides evidence that the progeny of infected female broodstock do not develop ISA in freshwater. Due to the limitations of space in the current study, it was not possible to include a positive control consisting of fertilised eggs injected with ISAV. To address the possibility of 'silent' freshwater infection, the surviving fish from the present study will be transferred to a recirculating marine quarantine unit in 1999 for further testing.

Acknowledgements. The authors gratefully acknowledge the excellent technical assistance of L. Hutchin, J. Lovely and B. McDonnell, and the cooperation of the New Brunswick Salmon Growers' Association and the New Brunswick Department of Fisheries and Aquaculture. The study was funded by the Industry/Government Haemorrhagic Kidney Syndrome (HKS) Committee. The authors would also like to acknowledge the generosity of A. Nylund, B. Dannevig, K. Falk and E. Rimstad in the provision of continued technical advice for ISAV management in Atlantic Canada

\section{LITERATURE CITED}

Byrne PJ, MacPhee DD, Ostland VE, Johnson G, Ferguson HW (1998) Haemorrhagic kidney syndrome of Atlantic salmon, Salmo salar L. J Fish Dis 21:81-91

Dannevig BH, Falk K, Namork E (1995) Isolation of the causal virus of infectious salmon anaemia (ISA) in a long-term cell line from Atlantic salmon head kidney. J Gen Virol 76: $1353-1359$

Editorial responsibility: Jo-Ann Leong,

Corvallis, Oregon, USA
Falk K, Namork E, Dannevig BH (1998) Characterisation and applications of a monoclonal antibody against infectious salmon anemia virus. Dis Aquat Org 34:77-85

Gnffiths SG, Liska K, Lynch WH (1996) Comparison of kidney tissue and ovarian fluid from broodstock Atlantic salmon for detection of Renibacterium salmoninarum, and use of SKDM broth culture with Western blotting to increase detection in ovarian fluid. Dis Aquat Org 24:3-9

Jarp J, Karlsen E (1997) Infectious salmon anaemia (ISA) risk factors in sea cultured Atlantic salmon Salmo salar L. Dis Aquat Org 28:79-86

Lovely JE, Dannevig BH, Falk K, Hutchin L, MacKinnon AM, Melville KJ, Rimstad E, Griffiths SG (1999) First identification of infectious salmon anaemia in North America with haemorrhagic kidney syndrome. Dis Aquat Org 35: 145-148

Mullins JE, Groman D, Wadowska D (1998) Infectious salmon anaemia in salt water Atlantic salmon (Salmo salar L.) in New Brunswick, Canada. Bull Eur Assoc Fish Pathol 18: $110-114$

Rodger HD, Turnbull T, Muir F, Millar S, Richards RH (1998) Infectious salmon anaemia (ISA) in the United Kingdom. Bull Eur Assoc Fish Pathol 18:115-116

Sellner LN, Turbett GR (1998) Comparison of three RT-PCR Methods. Biotechniques 25:230-234

Thorud KE, Djupvik HO (1988) Infectious salmon anaemia in Atlantic salmon (Salmo salar L.). Bull Eur Assoc Fish Pathol 8:109-111

Totland GK, Hjeltnes BK, Flood PR (1996) Transmission of infectious salmon anemia (ISA) through natural secretions and excretions from infected smolts of Atlantic salmon Salmo salar during their presymptomatic phase. Dis Aquat Org 26:25-31

Submitted: May 15, 1999; Accepted: July 16, 1999 Proofs received from author(s): November 4, 1999 